\title{
MODELING OF THE KINETICS OF CRYOGENIC FREEZING OF LIMA BEAN SEEDS AS A FUNCTION OF INITIAL WATER CONTENT
}

\author{
Karina M da F. Luciano ${ }^{1}$, Mario E. R. M. Cavalcanti Mata ${ }^{2 *}$, Mauri Fortes ${ }^{1}$, Maria E. M. Duarte ${ }^{3}$ \\ ${ }^{2 *}$ Corresponding author. Universidade Federal de Campina Grande/ Campina Grande - PB, Brasil. \\ E-mail: mcavalcantimata@gmail.com | ORCID ID: https://orcid.org/0000-0001-6919-207X
}

\section{KEYWORDS}

Phaseolus lunatus; Cryogenic; Modeling; Germplasm bank.

\begin{abstract}
Cryopreservation is a technique used to preserve genetic material at ultra-low temperatures in cryogenic germplasm banks. In order to enable the cryopreservation of a seed, it is necessary to study its appropriate freezing temperature and its water content, because seeds reach maximum physiological quality with high water contents, and they tolerate drying when they are orthodox seeds, but they may not tolerate cryopreservation. Therefore, the objective of this study was to analyze the influence of initial water content ( 50 to $10 \%$ wet basis) on the kinetic behavior of the lima bean seed at the temperature of $-150{ }^{\circ} \mathrm{C}$, in addition to determining changes in its physiological quality (germination and vigor) when cryopreserved $\left(-150^{\circ} \mathrm{C}\right)$ for 30 days with the variation of initial water contents (50 to $10 \%$ wet basis). For this purpose, changes in lima bean size (length, width, and thickness), sphere-equivalent radius and volume, and kinetics of seed cryopreservation as a function of its water content. The Fourier model and the CavalcantiMata \& Duarte models I and II were used for cryopreservation modeling, in addition to proposing a new model for cryopreservation kinetics in which water content determines the kinetic behavior. The conclusion was that the water content of $10 \% \mathrm{wb}$ should be used for the lima bean seed cryopreservation since its physiological quality was not affected by cryopreservation at $-150{ }^{\circ} \mathrm{C}$. The model that best represents the experimental data is Cavalcanti Mata \& Duarte Model II.
\end{abstract}

\section{INTRODUCTION}

Seed cryopreservation is a process studied worldwide to support plant species survival for indeterminate periods, avoiding genetic erosion. In this procedure, it is of major importance to define cryogenic temperatures able to cryofreeze seeds, as well as to determine an ideal water content for cryopreservation (Cavalcanti-Mata, 2015). It is necessary to decide how much water seeds should contain for the cryopreservation process, because according to the same author, if the water content is very low, they will abandon flexibility, producing cracks in their physical structures and causing cell ruptures. On the other hand, the use of very low temperatures during freezing, such as cryogenic temperatures (less than $-130^{\circ} \mathrm{C}$ ) makes it possible for seeds with high water content to have their ice crystals formed with a structure a thousand times smaller than that of non-cryogenic freezing $\left(-20^{\circ} \mathrm{C}\right)$. Therefore, the study of cryopreservation is primarily restricted to the study of adequate water content and the best cryogenic temperature in which seeds maintain their physiological quality (Goldfarb et al., 2017).

The lima bean seed reaches its physiological maturity point with water content between 45 and $50 \%$ wet basis (wb), from which it loses viability if not immediately cryopreserved or dried to a safe water content for its conservation, and later be cryopreserved (Cavalcanti-Mata, 2015). As the lima bean is an orthodox seed, that is, tolerates drying for conservation, and may not tolerate it for cryopreservation, the objective of this study was to analyze the freezing of lima bean seeds at a cryogenic temperature of $-150{ }^{\circ} \mathrm{C}$ for different water contents, ranging from the maximum physiological quality of $50 \% \mathrm{wb}$ to $10 \% \mathrm{wb}$; with the purpose of obtaining the best conservation in cryogenic germplasm bank. In order to achieve this goal, the specific objectives of this study were: a) to determine the size (length, width, and thickness), sphere-equivalent radius and volume of lima bean seeds as a function of water content $(50 \%, 40 \%, 30 \%, 20 \%$, and $10 \% \mathrm{wb}) ; \mathrm{b})$ to model freezing

\footnotetext{
${ }^{1}$ IETEC/ Belo Horizonte - MG, Brasil.

${ }^{3}$ Universidade Federal de Campina Grande/ Campina Grande - PB, Brasil.

Received in: 3-13-2018

Accepted in: 3-8-2019
} 
kinetics using the Fourier Model and Models I and II of Cavalcanti-Mata \& Duarte (2016) as a function of water content variation, besides proposing a new kinetic behavior model similar to that of pure water, which occurs when the lima bean seed has water contents of 50 and $40 \% \mathrm{wb}$; c) to determine the change in physiological quality (germination and vigor) of the lima bean seed when cryopreserved (-150 ${ }^{\circ} \mathrm{C}$ ) for 30 days with water contents ranging from 50 to $10 \%$ wet basis.

\section{MATERIAL AND METHODS}

This study was carried out in the cryogenic sector of the Laboratory of Cold Technology, belonging to the Academic Unit of Food Engineering, Federal University of Campina Grande (UFCG), Campina Grande-PB, Brazil, together with the Institute of Technological Education IETEC, in Belo Horizonte (MG).

Seeds were collected in the field with a water content of $50 \%$ wet basis (wb), close to the water content of their physiological maturity stage $(47 \% \mathrm{wb})$. Water content was determined following the Rules for Seed Testing, using an oven with air circulation at $105{ }^{\circ} \mathrm{C} \pm 3{ }^{\circ} \mathrm{C}$ for 48 hours (Brazil, 2012). Whole seed samples containing 100 units for each water content specified were collected randomly into the seed mass. Each seed had its orthogonal dimensions measured using a digital caliper model Mitutoyo, precision $0.01 \mathrm{~mm}$. A Mettler Toledo model MS-TS analytical scales with a resolution of 4 decimal digits was used for weighing the samples of 100 seeds for each water content specified $(10,20,30,40$, and $50 \% \pm 1 \% \mathrm{wb})$. Water contents were determined from the initial water content of $50 \% \pm 0.1 \%$, by drying in a desiccator and weighing every 30 minutes until reaching the weight equivalent to a water content of $40 \%$, when a new quantity of seeds was then separated for size determination. This sequence was also performed for the other determinations.

The lima bean seed volume was determined by the method described by Mohsenin (1980), based on the measurement of the 3 orthogonal axes of the seeds. The radii of each axis can be calculated by dividing the measurements of each of the axes by 2 , and seed volume can be obtained by the following formula:

$$
V_{\text {fava }}=\frac{4}{3} \pi\left(\frac{d_{1}}{2} \frac{d_{2}}{2} \frac{d_{3}}{2}\right)=\frac{1}{6} \pi\left(d_{1} d_{2} d_{3}\right)
$$

in which,

$$
\begin{aligned}
& \mathrm{d}_{1}=\text { diameter in the direction of the } \mathrm{X} \text {-axis, } \mathrm{mm} ; \\
& \mathrm{d}_{2}=\text { diameter in the direction of the } \mathrm{Y} \text {-axis, mm, } \\
& \mathrm{d}_{3}=\text { diameter in the direction of the } \mathrm{Z} \text {-axis, mm. }
\end{aligned}
$$

The equivalent radius of lima bean seeds could be determined by calculating the bean volume, considered as if it had the shape of a sphere, by means of the equation:

The study of freezing kinetics of lima bean seeds at $-150 \pm 1{ }^{\circ} \mathrm{C}$ was carried out using a double-stage horizontal cryogenic freezing unit and the information obtained at each time interval, starting with $10 \mathrm{sec}$. Temperatures were recorded using two $0.2-\mathrm{mm}$-diameter thermocouples connected to a two-channel Digi-Sensi recorder. Temperature records stopped when the thermocouple located inside the lima bean seed reached temperature values close to those of the freezing chamber $\left( \pm 1^{\circ} \mathrm{C}\right)$. The data used to obtain the freezing kinetics were the means of 3 replicates.

\section{Mathematical treatment}

The mathematical models used to describe the freezing kinetics of lima bean seeds at the cryogenic temperature of $-150{ }^{\circ} \mathrm{C}$ for initial water contents of $50 \%$, $40 \%, 30 \%, 20 \%$, and $10 \% \pm 0.1 \%$ wb were: a) the Fourier model, using the first term of the series, b) model I and II, proposed by Cavalcanti-Mata \& Duarte (2016), and c) model III, proposed in this study.

The Fourier model using the $1^{\text {st }}$ term of the series derives from the general equation of heat transfer:

$$
\frac{\partial T}{\partial t}=\frac{1}{r^{2}} \frac{\partial}{\partial r}\left(\alpha r^{2} \frac{\partial T}{\partial r}\right)
$$

Taking the geometric shape of a sphere, Apaci proposed the analytical solution of the [eq. (3)] when the temperature at the center of the sphere is known (Cavalcanti Mata, 2015).

$$
\frac{T-T_{\infty}}{T_{i}-T_{\infty}}=2 \sum_{n=1}^{\infty}\left(\frac{\operatorname{sen} M_{n}-M_{n} \cos M_{n}}{M_{n}-\operatorname{sen} M_{n} \cos n}\right) \exp M_{n}^{2} F_{o}
$$

Equation (4) can be written more simply by defining the following terms:

$$
\begin{aligned}
& R T=\frac{T-T_{\infty}}{T_{i}-T_{\infty}} \\
& \mathrm{J}=2 \sum_{n=1}^{\infty}\left(\frac{\operatorname{sen} M_{n}-M_{n} \cos M_{n}}{M_{n}-\operatorname{sen} M_{n} \cos M_{n}}\right) \\
& F_{o}=\frac{\alpha}{r_{m}^{2}} t
\end{aligned}
$$

By substituting these terms and taking into account the first term of the series in the [eq. (4)], the following equation is obtained:

$$
R T=J \exp \left(\alpha \frac{M_{1}^{2}}{r_{m}^{2}}\right) t
$$

in which

$$
\begin{aligned}
& k_{r} \text { is defined by [eq. (9)]. } \\
& k_{r}=\alpha \frac{M_{1}^{2}}{r_{m}^{2}}
\end{aligned}
$$

in which,

$$
\begin{aligned}
& \text { RT - temperature ratio, dimensionless; } \\
& \mathrm{T} \text { - product temperature at time } \mathrm{t},{ }^{\circ} \mathrm{C} ; \\
& \mathrm{T}_{\infty} \text { - freezing medium temperature, }{ }^{\circ} \mathrm{C} ; \\
& \mathrm{T}_{\mathrm{i}} \text { - initial product temperature, }{ }^{\circ} \mathrm{C} ; \\
& \mathrm{F}_{\mathrm{o}} \text { - Fourier number, dimensionless; } \\
& \mathrm{J} \text { - delay factor; } \\
& \mathrm{k}_{\mathrm{r}} \text { - cooling constant; } \\
& \mathrm{M}_{\mathrm{n}} \text { - transcendental root; } \\
& \alpha \text { - effective thermal diffusivity, } \mathrm{mm}^{2} \mathrm{~s}^{-1} ; \\
& \mathrm{r}_{\mathrm{m}} \text { - bean seed radius, mm, } \\
& \mathrm{t} \text { - time, } \mathrm{s} \text {. }
\end{aligned}
$$


In Model I of Cavalcanti-Mata \& Duarte (2016), the equation proposed is derived from the Fourier model, using the first term of the series. In this model, the authors state the existence of a potential correction in time, $\mathrm{N}$, written as follows:

$$
R T=J^{\prime} \exp \left(\alpha \frac{M_{1}^{2}}{r_{m}^{2}}\right) t^{N}
$$

in which,

$J^{\prime}$, the delay factor, varies between 1.01 and 1.04, and

$N$ is an empirical parameter.

In the empirical model II recommended by Cavalcanti-Mata \& Duarte (2016), the authors incorporate two coefficients in the freezing kinetics stating that there is a change in the curvature of the freezing curve in the kinetic behavior. In this case, the model proposed is expressed as:

$$
R T=A \exp \left(\frac{\varphi_{1}}{r_{m}^{2}}\right) t^{N_{1}}+B \exp \left(\frac{\varphi_{2}}{r_{m}^{2}}\right) t^{N_{2}}
$$

in which,

$$
\varphi_{1} \text { and } \varphi_{2} \text { - freezing kinetics constants, }
$$

$A, B, N_{1}$ and $N_{2}$ - empirical coefficients of the freezing equation.

The coefficients of these equations, $J, J,^{\prime}$ and $k$ were obtained by non-linear regression using the Statistica 8.0 software to determine the effective thermal diffusivity from eqs (5) and (10).

It was possible to obtain the activation energy, $E a$, taking into account the dependence of the effective thermal diffusivity, $\alpha$, with the temperature considered by the modified Arrhenius equation (Horn et al., 2010). However, since this determination is made for a single temperature, this activation energy must also be changed as a function of water content. Thus, the Arrhenius equation was modified to:

$$
\alpha=A_{1}+\left[D_{0} \exp \left(\frac{E_{a}}{R T}\right)\right] X
$$

in which,

$$
\begin{aligned}
& A_{1} \text { - constant of the equation; } \\
& D_{0} \text { - constant, } \mathrm{m}^{2} \mathrm{~s}^{-1} \\
& E_{a} \text { - activation energy, } \mathrm{J} \mathrm{mol}^{-1} ; \\
& R \text { - universal gas constant, } 8,314 \mathrm{~J} \mathrm{~mol}^{-1} \mathrm{~K}^{-1} ; \\
& T \text { - absolute temperature, } \mathrm{K}, \\
& X \text { - water content, } \% \text { wet basis. }
\end{aligned}
$$

For seeds with water contents of 50 and $40 \% \mathrm{wb}$, in which water predominates over dry matter and the kinetic behavior of cryopreservation is similar to that of pure water, the proposal is a model derived and adapted from the pharmaceutical equation of a double dose response in the program for charting and data analysis (Origin 8.0, 2016).
Thus, the model proposed can be written as:

$$
R T=A_{1}+\left(A_{2}-A_{1}\right)\left[\frac{p}{1+10^{\log \left(x_{1}-t\right) h_{1}}}+\frac{(1-p)}{1+10^{\log \left(x_{2}-t\right) h_{2}}}\right]
$$

in which,

$$
\mathrm{A}_{1} \cong 0 \text { and } \mathrm{A}_{2}=1,0 \text { or very close to these values. }
$$

Non-linear regression analyses were performed by the Gauss-Newton method for adequacy of the models. In each model, the coefficient of determination $\left(R^{2}\right)$, the estimated mean error $(S E)$ and the relative mean error $(P)$ were taken as follows.

$$
\begin{aligned}
& S E=\sqrt{\frac{\sum\left(R T_{\text {exp }_{i}}-R T_{\text {pre }}\right)_{i}}{G L R}} \\
& P=\frac{100}{n} \sum_{i=1}^{n}\left[\frac{\left|R T_{\exp _{i}}-R T_{\text {pre }_{i}}\right|}{R T_{\exp _{i}}}\right]
\end{aligned}
$$

in which,

$$
\begin{aligned}
& R T_{\text {pre }_{i}} \text { is the temperature ratio predicted by the model; } \\
& R T_{\exp _{i}} \text { is the experimental temperature ratio; } \\
& n \text { is the number of experiment observations, and } \\
& G L R \text { is the number of degrees of freedom of the model. }
\end{aligned}
$$

The values estimated were correlated with the values of residues for each regression equation. When the dispersion of these data does not characterize some type of behavior, the data is said to present a random behavior (A), and when the data present some type of defined behavior, that implies in a biased behavior (B).

To obtain the seed germination index before and after the cryofreezing process ( 30 days), they were seeded in plastic trays, using moistened vermiculite with an amount of water equivalent to $60 \%$ of the retention capacity. Trays were placed in germination chambers with temperature controlled at $25{ }^{\circ} \mathrm{C}$. Germination tests were conducted following the Rules for Seed Testing (Brasil, 2009), by counting the seedlings that emerged on the fifth day (first count) and ninth day (second count). Germinated plants were considered those with seedlings of perfect essential structures, with results expressed in percentages.

The vigor of the lima bean seeds was obtained as a function of the number of germinated seeds resulting from the first germination test count $\left(5^{\text {th }}\right.$ day). Results are expressed in percentages.

The lima bean seeds were placed in desiccators with a false bottom containing 300 grams of silica gel to establish the water contents to be studied $(50 \%, 40 \%, 30 \%, 20 \%$, and $10 \% \mathrm{wb}$ ). This procedure had the purpose of drying the lima bean seeds until reaching the water content values desired. Results were analyzed using a completely randomized experimental design with $5 \times 2$ factorial arrangement, represented by water contents of $10 ; 20 ; 30 ; 40$, and $50 \%$ in $\mathrm{wb}$ and storage period of 0 and 30 days, using four replicates of 50 seeds per treatment. The results were submitted to analysis of variance and the means of the treatments were compared by the Tukey test at a 5\% significance level using the Assistat software (Santos and Silva \& Azevedo, 2016). 


\section{RESULTS AND DISCUSSION}

Table 1 shows the variations of length, width, thickness, volume, and radius of the equivalent sphere of the lima bean as a function of water content. These data indicate that the length of the lima bean seed shows a greater reduction with the decrease in water content than width and thickness. These differences are also reported by several authors for different seeds or even for the different varieties of lima beans (Guimarães et al., 2007, Frazão et al., 2010; Oliveira et al., 2011). This larger reduction can be explained by the longer seed length compared to the other dimensions, due to the greater path for water diffusion and greater surface area along the length, allowing the escape of more water.

It is further noted that the radius of an equivalent sphere decreases with decreasing water content. This finding is significant for the freezing process, because as the seed size becomes different, the freezing constant is also different and, as a consequence, thermal diffusivity must be affected. This finding was reported by Cavalcanti Mata et al. (2012) when studying the kinetics of cryopreservation in bean seeds.

TABLE 1. Physical characteristics of lima bean seeds according to water content.

\begin{tabular}{lccccc}
\hline \multirow{2}{*}{ Parameters } & \multicolumn{4}{c}{ Water content, \% wet basis } \\
\cline { 2 - 5 } & 10 & 20 & 30 & 40 & 50 \\
\hline Length, mm & 15.968 & 16.614 & 16.963 & 17.766 & 20.756 \\
Width, mm & 11.079 & 11.176 & 11.506 & 11.642 & 13.412 \\
Thickness, mm & 5.626 & 5.631 & 5.999 & 6.274 & 6.582 \\
Volume, $\mathrm{mm}^{3}$ & 521.485 & 546.363 & 614.217 & 679.238 & 966.319 \\
Radius of equivalent sphere, $\mathrm{mm}$ & 4.983 & 5.065 & 5.265 & 5.446 & 6.114 \\
\hline
\end{tabular}

Figure 1 shows the variation of experimental data of the cryopreservation kinetics of lima bean seeds at $-150{ }^{\circ} \mathrm{C}$ for water contents varying from 50 to $10 \% \mathrm{wb}$.

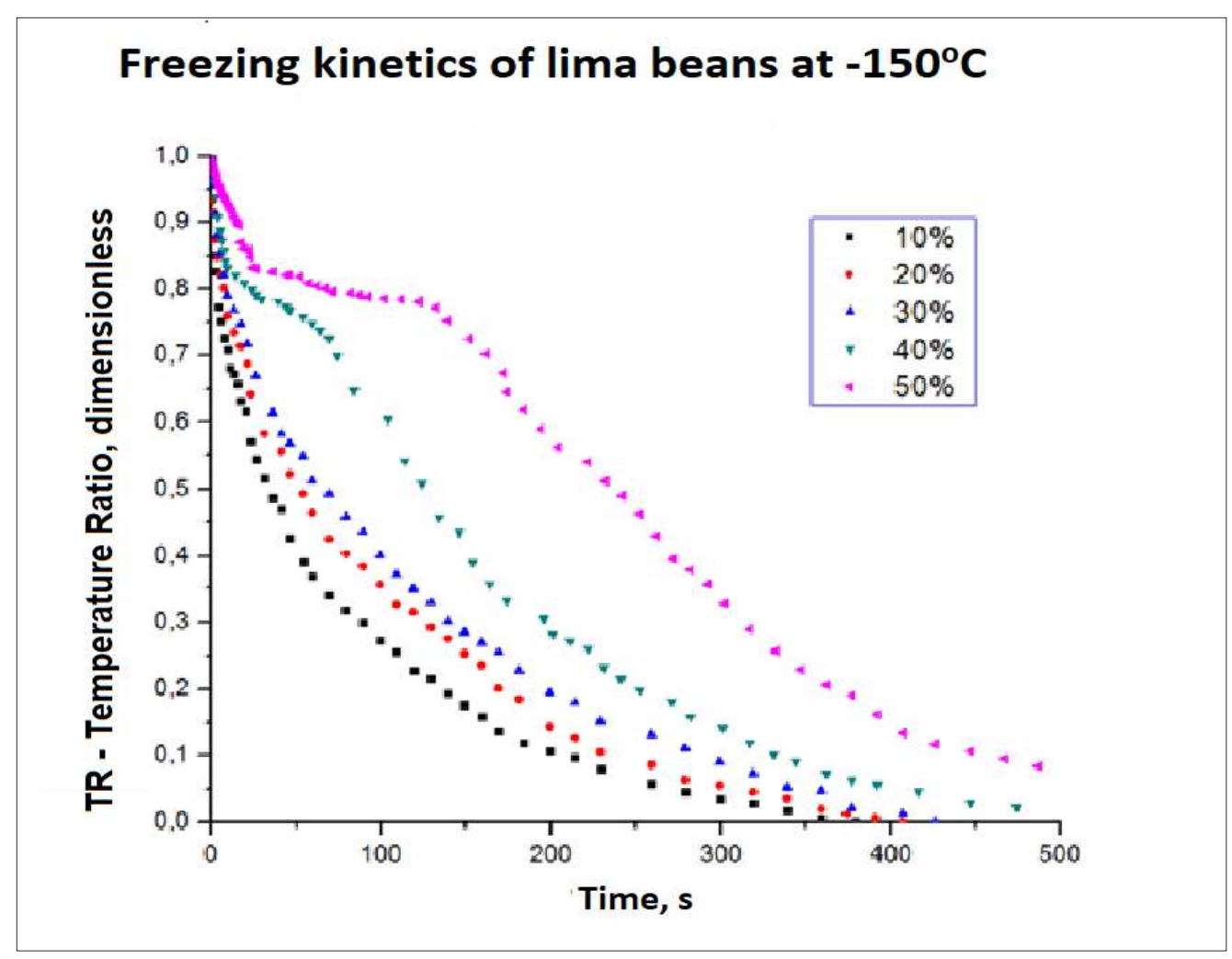

FIGURE 1. Experimental data of the freezing kinetics of the lima bean seed at $-150{ }^{\circ} \mathrm{C}$ for water contents of $10,20,30,40$, and $50 \%$ wb.

The following models were used to represent the kinetic behavior of the lima bean freezing with water contents of $10 \%, 20 \%$ and, $30 \%$ : the Fourier model with only the first term of the series, model I by Cavalcanti-Mata \& Duarte, which is a semi-theoretical model, and model II by Cavalcanti-Mata $\&$ Duarte, which is an empirical model. The models employed are divided into three phases for the lima bean freezing with water contents of $40 \%$ and $50 \% \mathrm{wb}$
Phase I is cooling, Phase II is crystallization, and Phase III is freezing.

The values of coefficients of the lima bean freezing curve expressed by the equations proposed in this study, considering the variation of the seed radius, which is considered as an equivalent sphere, are show for the Fourier model using the first term of the series in Table 2, in Table 3 for Model I by Cavalcanti-Mata \& Duarte, and in Table 4 for model II by Cavalcanti-Mata \& Duarte. 
TABLE 2. Parameters of the freezing kinetics of lima bean seeds at $-150{ }^{\circ} \mathrm{C}$ for the Fourier model using the $1^{\text {st }}$ term of the series.

\begin{tabular}{|c|c|c|c|c|c|c|c|c|c|c|c|}
\hline \multicolumn{12}{|c|}{ Fourier Model (1st term of the series). Dry matter dominance in kinetics. } \\
\hline $\begin{array}{c}\mathrm{X}^{*} \\
\% w b\end{array}$ & $\mathrm{~J}$ & $\frac{M_{1}^{2} \alpha}{r_{m}^{2}}$ & $\begin{array}{c}r_{m} \\
\mathrm{~mm}\end{array}$ & $\begin{array}{c}r_{m}^{2} \\
\mathrm{~mm}\end{array}$ & $M_{1}$ & $M_{1}^{2}$ & $\begin{array}{c}\alpha \\
\mathrm{mm}^{2} / \mathrm{s}\end{array}$ & $\mathrm{R}^{2}$ & SE & $\mathrm{P}(\%)$ & Residue \\
\hline 10 & 1.01 & 0.01779 & 4.983 & 24.83 & 0.3347 & 0.11202 & 3.9433 & 90.05 & 0.09325 & 35.29 & $\mathrm{~B}$ \\
\hline 20 & 1.01 & 0.01175 & 5.065 & 25.65 & 0.3347 & 0.11202 & 2.6905 & 94.14 & 0.07606 & 22.52 & $\mathrm{~B}$ \\
\hline 30 & 1.01 & 0.00986 & 5.265 & 27.72 & 0.3347 & 0.11202 & 2.4399 & 95.09 & 0.06955 & 18.56 & $\mathrm{~B}$ \\
\hline \multicolumn{12}{|c|}{ Fourier Model (1st term of the series). Water dominance in kinetics. } \\
\hline \multirow{6}{*}{40} & $\mathrm{~J}_{\text {liq }}$ & $\frac{M_{1}^{2} \alpha}{r_{m}^{2}}$ & $\begin{array}{c}r_{m} \\
\mathrm{~mm}\end{array}$ & $\begin{array}{c}r_{m}^{2} \\
\mathrm{~mm}\end{array}$ & $M_{1}$ & $M_{1}^{2}$ & $\begin{array}{c}\alpha \\
\mathrm{mm}^{2} / \mathrm{s}\end{array}$ & $\mathrm{R}^{2}$ & SE & $\mathrm{P}(\%)$ & \\
\hline & 0.992429 & 0.020837 & 5.446 & 29.65 & 4.0323 & 16.259443 & 0.038 & 98.61 & 0.007112 & 0.61 & B \\
\hline & $\mathrm{J}_{\text {cris }}$ & $\frac{M_{1}^{2} \alpha}{r_{m}^{2}}$ & $\begin{array}{c}r_{m} \\
\mathrm{~mm}\end{array}$ & $\begin{array}{c}r_{m}^{2} \\
\mathrm{~mm}\end{array}$ & $M_{1}$ & $M_{1}^{2}$ & $\begin{array}{c}\alpha \\
\mathrm{mm}^{2} / \mathrm{s}\end{array}$ & $\mathrm{R}^{2}$ & SE & $\mathrm{P}(\%)$ & \\
\hline & 0.839225 & 0.00198 & 5.446 & 29.65 & - & - & - & 97.41 & 0.0046410 & 0.49 & $\mathrm{R}$ \\
\hline & $\mathrm{J}_{\text {freez }}$ & $\frac{M_{1}^{2} \alpha}{r_{m}^{2}}$ & $\begin{array}{c}r_{m} \\
\mathrm{~mm} \\
\end{array}$ & $\begin{array}{c}r_{m}^{2} \\
\mathrm{~mm}\end{array}$ & $M_{1}$ & $M_{1}^{2}$ & $\begin{array}{c}\alpha \\
\mathrm{mm}^{2} / \mathrm{s}\end{array}$ & $\mathrm{R}^{2}$ & SE & $\mathrm{P}(\%)$ & \\
\hline & 0.820172 & 0.00732 & 5.446 & 29.65 & 4.1127 & 16.91 & 0.0129 & 99.66 & 0.013507 & 10.00 & $\mathrm{R}$ \\
\hline \multirow{6}{*}{50} & $\mathrm{~J}_{\text {liq }}$ & $\frac{M_{1}^{2} \alpha}{r_{m}^{2}}$ & $\begin{array}{c}r_{m} \\
\mathrm{~mm}\end{array}$ & $\begin{array}{c}r_{m}^{2} \\
\mathrm{~mm}\end{array}$ & $M_{1}$ & $M_{1}^{2}$ & $\begin{array}{c}\alpha \\
\mathrm{mm}^{2} / \mathrm{s}\end{array}$ & $\mathrm{R}^{2}$ & SE & $\mathrm{P}(\%)$ & \\
\hline & 0.981002 & 0.005637 & 6.114 & 37.38 & 4.0377 & 16.30302 & 0.0129 & 92.19 & 0.0055514 & 0.48 & B \\
\hline & $\mathrm{J}_{\text {cris }}$ & $\frac{M_{1}^{2} \alpha}{r_{m}^{2}}$ & $\begin{array}{c}r_{m} \\
\mathrm{~mm}\end{array}$ & $\begin{array}{c}r_{m}^{2} \\
\mathrm{~mm}\end{array}$ & $M_{1}$ & $M_{1}^{2}$ & $\begin{array}{c}\alpha \\
\mathrm{mm}^{2} / \mathrm{s}\end{array}$ & $\mathrm{R}^{2}$ & SE & $\mathrm{P}(\%)$ & \\
\hline & 0.844514 & 0.000729 & 6.114 & 37.38 & - & - & - & 92.06 & 0.0043542 & 0.46 & B \\
\hline & $\mathrm{J}_{\text {freez }}$ & $\frac{M_{1}^{2} \alpha}{r_{m}^{2}}$ & $\begin{array}{c}r_{m} \\
\mathrm{~mm}\end{array}$ & $\begin{array}{c}r_{m}^{2} \\
\mathrm{~mm}\end{array}$ & $M_{1}$ & $M_{1}^{2}$ & $\begin{array}{c}\alpha \\
\mathrm{mm}^{2} / \mathrm{s}\end{array}$ & $\mathrm{R}^{2}$ & SE & $\mathrm{P}(\%)$ & \\
\hline & 1.118195 & 0.00588 & 6.114 & 37.38 & 1.0607 & 1.12508 & 0.1956 & 98.90 & 0.02825 & 17.41 & $\mathrm{~B}$ \\
\hline
\end{tabular}

$\mathrm{X}^{*}=$ Water content; $\mathbf{J}_{\text {liq }}=$ liquid phase; $\mathbf{J}_{\text {cris }}=$ crystallization phase; $\mathbf{J}_{\text {freez }}=$ freezing phase; B = Biased; R = Random.

TABLE 3. Parameters of lima bean freezing kinetics $-150{ }^{\circ} \mathrm{C}$ for Model I by Cavalcanti-Mata \& Duarte.

Cavalcanti-Mata \& Duarte Model I. Dry matter dominance in kinetics.

\begin{tabular}{|c|c|c|c|c|c|c|c|c|c|c|c|}
\hline $\begin{array}{l}X^{*} \\
\text { wb } \\
\end{array}$ & $\mathrm{J}$ & $\frac{M_{1}^{2} \alpha}{r_{m}^{2}}$ & $\begin{array}{r}r_{m} \\
\mathrm{~mm}\end{array}$ & $\begin{array}{c}r_{m}^{2} \\
\mathrm{~mm} 2\end{array}$ & M1 & $\mathrm{M}^{2} 1$ & $\begin{array}{c}\alpha \\
\mathrm{mm}^{2} / \mathrm{s}\end{array}$ & $\mathrm{R}^{2}$ & SE & $\mathrm{P}(\%)$ & Residue \\
\hline 10 & 1.01 & 0.08532 & 4.983 & 24.83 & 0.3347 & 0.11202 & 18.9117 & 99.14 & 0.02774 & 10.24 & B \\
\hline 20 & 1.01 & 0.0525 & 5.065 & 25.65 & 0.3347 & 0.11202 & 12.0213 & 99.00 & 0.03311 & 12.82 & B \\
\hline 30 & 1.01 & 0.04121 & 5.265 & 27.72 & 0.3347 & 0.11202 & 10.1976 & 99.10 & 0.03017 & 10.61 & $\mathrm{~B}$ \\
\hline \multicolumn{12}{|c|}{ Modelo I Cavalcanti- Mata \& Duarte. Domínio da água na cinética. } \\
\hline \multirow{6}{*}{40} & $\mathrm{~J}_{\text {liq }}$ & $\frac{M_{1}^{2} \alpha}{r_{m}^{2}}$ & $\begin{array}{c}r_{m} \\
\mathrm{~mm}\end{array}$ & $\begin{array}{c}r_{m}^{2} \\
\mathrm{~mm}\end{array}$ & $M_{1}$ & $M_{1}^{2}$ & $\begin{array}{c}\alpha \\
\mathrm{mm}^{2} / \mathrm{s} \\
\end{array}$ & $\mathrm{R}^{2}$ & SE & $\mathrm{P}(\%)$ & \\
\hline & 1.0097 & 0.04763 & 5.446 & 29.65 & 0.3111 & 0.09678 & 14.597 & 96.87 & 0.0125 & 1.07 & $\mathrm{~B}$ \\
\hline & $\mathrm{J}_{\text {cris }}$ & $\frac{M_{1}^{2} \alpha}{r_{m}^{2}}$ & $\begin{array}{c}r_{m} \\
\mathrm{~mm}\end{array}$ & $\begin{array}{c}r_{m}^{2} \\
\mathrm{~mm}\end{array}$ & $M_{1}$ & $M_{1}^{2}$ & $\begin{array}{c}\alpha \\
\mathrm{mm}^{2} / \mathrm{s}\end{array}$ & $\mathrm{R}^{2}$ & SE & $\mathrm{P}(\%)$ & \\
\hline & 0.4947 & 0.76137 & 5.446 & 29.65 & - & - & - & 91.96 & 0.00893 & 0.79 & $\mathrm{~B}$ \\
\hline & $J_{\text {freez }}$ & $\frac{M_{1}^{2} \alpha}{r_{m}^{2}}$ & $\begin{array}{c}r_{m} \\
\mathrm{~mm}\end{array}$ & $\begin{array}{c}r_{m}^{2} \\
\mathrm{~mm}\end{array}$ & $M_{1}$ & $M_{1}^{2}$ & $\begin{array}{c}\alpha \\
\mathrm{mm}^{2} / \mathrm{s}\end{array}$ & $\mathrm{R}^{2}$ & SE & $\mathrm{P}(\%)$ & \\
\hline & 0.7775 & 0.00389 & 5.446 & 29.65 & 4.132 & 17.0767 & 0.0068 & 99.78 & 0.01044 & 8.58 & $\mathrm{R}$ \\
\hline \multirow{6}{*}{50} & $\mathrm{~J}_{\text {liq }}$ & $\frac{M_{1}^{2} \alpha}{r_{m}^{2}}$ & $\begin{array}{r}r_{m} \\
\mathrm{~mm} \\
\end{array}$ & $\begin{array}{r}r_{m}^{2} \\
\mathrm{~mm} \\
\end{array}$ & $M_{1}$ & $M_{1}^{2}$ & $\begin{array}{c}\alpha \\
\mathrm{mm}^{2} / \mathrm{s}\end{array}$ & $\mathrm{R} 2$ & SE & $\mathrm{P}(\%)$ & \\
\hline & 0.9972 & 0.0110 & 6.114 & 37.38 & 4.03 & 16.241 & 0.0254 & 98.86 & 0.00549 & 0.44 & B \\
\hline & $\mathrm{J}_{\text {cris }}$ & $\frac{M_{1}^{2} \alpha}{r_{m}^{2}}$ & $\mathrm{~mm}$ & $\begin{array}{c}r_{m}^{2} \\
\mathrm{~mm} \\
\end{array}$ & $M_{1}$ & $M_{1}^{2}$ & $\begin{array}{c}\alpha \\
\mathrm{mm}^{2} / \mathrm{s}\end{array}$ & $\mathrm{R} 2$ & SE & $\mathrm{P}(\%)$ & \\
\hline & 0.6373 & 0.52421 & 6.114 & 37.38 & - & - & - & 93.81 & 0.00445 & 0.36 & $\mathrm{~B}$ \\
\hline & $\mathrm{J}_{\text {freez }}$ & $\frac{M_{1}^{2} \alpha}{r_{m}^{2}}$ & $\begin{array}{c}r_{m} \\
\mathrm{~mm}\end{array}$ & $\begin{array}{c}r_{m}^{2} \\
\mathrm{~mm}\end{array}$ & $M_{1}$ & $M_{1}^{2}$ & $\begin{array}{c}\alpha \\
\mathrm{mm}^{2} / \mathrm{s}\end{array}$ & $\mathrm{R} 2$ & SE & $\mathrm{P}(\%)$ & \\
\hline & 1.0761 & 0.00571 & 6.114 & 37.38 & 0.858 & 0.73616 & 0.2905 & 98.83 & 0.02834 & 18.07 & $\mathrm{~B}$ \\
\hline
\end{tabular}

$\mathrm{X}^{*}=$ Water content; $\mathbf{J}_{\text {liq }}=$ liquid phase; $\mathbf{J}_{\text {cris }}=$ crystallization phase; $\mathbf{J}_{\text {freez }}=$ freezing phase; B = Biased; R = Random. 
Tables 2 and 3 show the values of the freezing kinetic parameters of lima bean seeds frozen at $-150{ }^{\circ} \mathrm{C}$. Thermal diffusivity is observed to decrease with increasing seed water content for the lima bean seed with water content between $10 \%$ and $30 \% \mathrm{wb}$ This behavior stems from the concentration of water inside the seed, as water requires more energy for freezing than the product dry matter. The Fourier model and model I by Cavalcanti Mata \& Duarte also show that there is a decrease in thermal diffusivity when the product water content increases, for water contents of $40 \%$ and $50 \%$ wb in the first phase of the process. However, an inverse behavior is observed in the third stage, as there is an increase in thermal diffusivity with the increase in water content from $40 \%$ to $50 \%$ wb This finding can be explained by the difference in the seed kinetic behavior with these different water contents, and the water crystallization phase is verified to be better defined for a water content of $50 \% \mathrm{wb}$ than for a water content of $40 \% \mathrm{wb}$

TABLE 4. Parameters of lima bean seeds freezing kinetics at $-150{ }^{\circ} \mathrm{C}$ for Model II by Cavalcanti-Mata \& Duarte.

\begin{tabular}{|c|c|c|c|c|c|c|c|c|c|c|c|}
\hline \multicolumn{12}{|c|}{ Cavalcanti-Mata \& Duarte Model II. Dry matter dominance in kinetics. } \\
\hline $\begin{array}{c}X * \\
(\% w b)\end{array}$ & $\mathbf{A}_{\text {liq }}$ & $\frac{\varphi_{1}}{r_{m}^{2}}$ & $N_{1}$ & $r_{m}^{2}$ & $B_{\text {liq }}$ & $\frac{\varphi_{2}}{r_{m}^{2}}$ & $N_{2}$ & $\mathbf{R}^{2}$ & SE & $\begin{array}{c}P \\
(\%)\end{array}$ & Residue \\
\hline 10 & 0.59476 & 0.00926 & 0.99949 & 24.83 & 0.40524 & 0.32228 & 0.46436 & 99.70 & 0.02750 & 9,76 & B \\
\hline 20 & 0.30955 & 0.00022 & 1.62527 & 25.65 & 0.69045 & 0.10878 & 0.58386 & 99.83 & 0.01389 & 7,01 & $\mathrm{R}$ \\
\hline 30 & -0.46390 & 0.04312 & $4.02 \times 10^{-10}$ & 27.72 & 1.46347 & 0.04840 & 0.53200 & 99.89 & 0.01098 & 4,53 & $\mathrm{R}$ \\
\hline \multicolumn{12}{|c|}{ Cavalcanti-Mata \& Duarte Model II. Water dominance in kinetics. } \\
\hline \multirow{6}{*}{40} & Aliq & $\frac{\varphi_{1}}{r_{m}^{2}}$ & $N_{1}$ & $r_{m}^{2}$ & B $_{\text {liq }}$ & $\frac{\varphi_{2}}{r_{m}^{2}}$ & $N_{2}$ & $\mathbf{R}^{2}$ & SE & $\begin{array}{c}P \\
(\%) \\
\end{array}$ & \\
\hline & 0.58093 & 0.08671 & 1.00108 & 29.65 & 0.418749 & 0.055439 & 0.78201 & 99.78 & 0.00424 & 0,27 & $\mathrm{R}$ \\
\hline & Acris & $\frac{\varphi_{1}}{r_{m}^{2}}$ & $N_{1}$ & $r_{m}^{2}$ & $B_{\text {cris }}$ & $\frac{\varphi_{2}}{r_{m}^{2}}$ & $N_{2}$ & $\mathbf{R}^{2}$ & SE & $\begin{array}{c}P \\
(\%) \\
\end{array}$ & \\
\hline & 0.27399 & 0.979026 & 0.09515 & 29.65 & -0.10158 & 1.08866 & 0.0879 & 92.46 & 0.0106 & 0,77 & B \\
\hline & $A_{\text {freez }}$ & $\frac{\varphi_{1}}{r_{m}^{2}}$ & $N_{1}$ & $r_{m}^{2}$ & B $_{\text {cong }}$ & $\frac{\varphi_{2}}{r_{m}^{2}}$ & $N_{2}$ & $\mathbf{R}^{2}$ & SE & $\begin{array}{c}P \\
(\%) \\
\end{array}$ & \\
\hline & 0.72343 & 0.00287 & 1.15972 & 29.65 & 0.04453 & 0.000278 & 1.98666 & 99.81 & 0.01035 & 1,91 & B \\
\hline \multirow{6}{*}{50} & $A_{\text {liq }}$ & $\frac{\varphi_{1}}{r_{m}^{2}}$ & $N_{1}$ & $r_{m}^{2}$ & $B_{\text {liq }}$ & $\frac{\varphi_{2}}{r_{m}^{2}}$ & $N_{2}$ & $\mathbf{R}^{2}$ & SE & $\begin{array}{c}P \\
(\%) \\
\end{array}$ & \\
\hline & 0.3995 & 0.005014 & 1.2659 & 37.38 & 0.600138 & 0.02387 & 0.4683 & 99.10 & 0.00477 & 0,41 & B \\
\hline & $\mathbf{A}_{\text {cris }}$ & $\frac{\varphi_{1}}{r_{m}^{2}}$ & $N_{1}$ & $r_{m}^{2}$ & $\mathbf{B}_{\text {cris }}$ & $\frac{\varphi_{2}}{r_{m}^{2}}$ & $N_{2}$ & $\mathbf{R}^{2}$ & SE & $\begin{array}{c}\mathbf{P} \\
(\%) \\
\end{array}$ & \\
\hline & 0.0655 & 0.54815 & 0.0257 & 37.38 & 0.45778 & 0.73031 & 0.14548 & 94.08 & 0.004194 & 0,34 & B \\
\hline & Afreez $_{\text {fre }}$ & $\frac{\varphi_{1}}{r_{m}^{2}}$ & $N_{1}$ & $r_{m}^{2}$ & B cong & $\frac{\varphi_{2}}{r_{m}^{2}}$ & $N_{2}$ & $\mathbf{R}^{2}$ & SE & $\begin{array}{c}\mathbf{P} \\
(\%) \\
\end{array}$ & \\
\hline & 1.53071 & 4.49816 & 0.32395 & 37.38 & -2.4584 & 11.95193 & 0.74817 & 99.03 & 0.02537 & 14,8 & $\mathrm{~B}$ \\
\hline
\end{tabular}

$\mathrm{X}^{*}=$ Water content; $\mathrm{B}=$ Biased; $\mathrm{R}=$ Random.

Table 4 shows Model II by Cavalcanti-Mata \& Duarte, which is an empirical model. The objective of this equation is to better express the experimental data of the lima bean seed freezing process. The empirical model II by Cavalcanti-Mata \& Duarte is observed to fit better to the experimental data, since the coefficients of determination for water contents varying from $10 \%$ to $50 \%$ wb are greater than $99 \%$, and relative errors less than $10 \%$. As this model is empirical, it does not allow to determine the thermal diffusivity of the lima bean seed freezing kinetics and, rather, the freezing constants $\left(\varphi_{1}\right.$ e $\left.\varphi_{2}\right)$. It should be noted that the statements reported here are true for water contents of 40 and $50 \% \mathrm{wb}$ during the cooling and freezing phases, which are characteristic of the freezing kinetics, disregarding the crystallization phase, in which all the energy "spent" in the process is in theory used to form the water crystals inside the lima bean seed. In conclusion, the coefficients of determination for model II are considered very good, indicating that the experimental and calculated data express the lima bean freezing phenomenon adequately. According to Mohapatra \& Rao (2005) cited by Goneli et al., (2014), there is a good fit to the model only if the relative mean error $(\mathrm{P})$ is less than $10 \%$. Thus, the
Fourier model using the first term of the series expresses the freezing kinetics, with some limitation. However, since only the first term in the series was used in this equation, it is assumed that the coefficient of determination can be improved as the number of terms in the series increases. Nevertheless, the coefficients of determination are observed to be higher in model II by Cavalcanti-Mata \& Duarte, indicating that this model can be used and, therefore, it is not necessary to increase the number of Fourier series terms.

Several authors, among them Amaral et al. (2010) and Feitosa et al. (2017) have studied the freezing kinetics and the effective thermal diffusivity as a function of seed cryogenic freezing, respectively of chickpeas and lima beans, and have concluded that effective thermal diffusivity increases with decreasing temperature. However, thermal diffusivity can also be influenced by seed water content and composition.

A good match between the experimental data and the calculated data is observed through the coefficients of determination when comparing model I by Cavalcanti-Mata $\&$ Duarte to the Fourier model using the first term of the series, which makes it possible to find the effective thermal diffusivity of the lima bean freezing. The importance of 
obtaining the effective thermal diffusivity refers to the need to calculate the heat transfer of products, to determine the apparent thermal conductivity as a function of freezing speed, to design industrial equipment and to promote the simulation of freezing processes (Incropera \& DeWitt, 1996; Silva et al., 2015).

The freezing kinetics of lima bean with water contents of $40 \%$ and $50 \%$ wb has a behavior similar to that of pure water. Thus, three phases are identified during the lima bean seed freezing with water contents of $40 \%$ and $50 \%$ wb: cooling, crystallization, and freezing. The characteristics of this freezing kinetics do not allow the application of the Fourier model that expresses the behavior as a whole. Therefore, a new model (Equation 14) was proposed to represent the kinetic behavior for water contents of 40 and $50 \% \mathrm{wb}$

Table 5 shows the freezing kinetic parameters of the lima bean seed at $-150{ }^{\circ} \mathrm{C}$. In the model proposed, it is possible to analyze thermal diffusivity at two points identified as $h_{1}$ and $h_{2}$ for $40 \%$ and $50 \%$ wb Based on this model, the higher the product water content, the greater its thermal diffusivity. In this case, for the water content of $40 \% \mathrm{wb}, \mathrm{h}_{1}=0.03676$ and $\mathrm{h}_{2}=0.0031$. For the water content of $50 \% \mathrm{wb}, \mathrm{h}_{1}=0.07038$ and $\mathrm{h}_{2}=0.00547$. The relative mean error is other important data for this model, with a value of 0.05103 for the water the content of $40 \% \mathrm{wb}$ and $0.165 \%$ for the water content of $50 \% \mathrm{wb}$.

TABLE 5. Parameters of the freezing kinetics of lima bean seeds at $-150{ }^{\circ} \mathrm{C}$ for water contents of 40 and $50 \%$ wb - Model Proposed.

\begin{tabular}{|c|c|c|c|c|c|c|c|c|c|}
\hline & & & & Model pr & osed-Cav & anti Mata & Duarte & & \\
\hline $\begin{array}{c}X * \\
\% \text { wb }\end{array}$ & $A_{1}$ & $A_{2}$ & $\log X_{1}$ & $\log X_{2}$ & $h_{1}$ & $h_{2}$ & $\mathbf{R}^{2}$ & $\mathbf{P}$ & Residue \\
\hline $\begin{array}{l}40 \\
50\end{array}$ & $\begin{array}{c}-0.02703 \\
0.02193\end{array}$ & $\begin{array}{l}1.88261 \\
1.05358\end{array}$ & $\begin{array}{l}129.555 \\
8.73514\end{array}$ & $\begin{array}{l}-19.745 \\
256.106\end{array}$ & $\begin{array}{l}-0.03676 \\
-0.07038\end{array}$ & $\begin{array}{c}-0.0031 \\
-0.00547\end{array}$ & $\begin{array}{l}99.36 \\
99.85\end{array}$ & $\begin{array}{l}0.05103 \\
0.16512\end{array}$ & $\begin{array}{l}\text { Biased } \\
\text { Biased }\end{array}$ \\
\hline
\end{tabular}

$\mathrm{X}^{*}=$ Water contente.

The comparison of the thermal diffusivity found in the different models (Table 6) shows that the values are in the same order of magnitude when comparing the Fourier model using the first term of the series with the model proposed for the lima bean seed with water content of $40 \%$ wb This can also be observed for the cooling period of the lima bean seed with water content of $50 \%$ wb However, for the portion of the curve corresponding to the lima bean freezing, the thermal diffusivity value is smaller in the order of two-digit magnitude. Therefore, the possible conclusion is that the alternative model proposed can be applied to the water content of $40 \% \mathrm{w} . \mathrm{b}$ for the freezing of bean seeds at $150^{\circ} \mathrm{C}$, but the application is not advisable to express the freezing kinetics in the third stage of the process for the water content of $50 \% \mathrm{wb}$.

TABLE 6. Effective thermal diffusivity of the different models studied for the freezing of lima bean seeds with water contents of 40 and $50 \% \mathrm{wb}$, at a temperature of $-150{ }^{\circ} \mathrm{C}$.

\begin{tabular}{|c|c|c|c|}
\hline $\begin{array}{c}\mathrm{X} * \\
\% \mathrm{wb}\end{array}$ & Phases & $\begin{array}{c}\text { Fourier Model } \\
1^{\text {st }} \text { term of the series } \alpha \mathrm{mm}^{2} / \mathrm{s}\end{array}$ & $\begin{array}{c}\text { Model Proposed } \\
\alpha \mathrm{mm}^{2} / \mathrm{s} \\
\end{array}$ \\
\hline \multirow{3}{*}{$40 \%$} & Cooling & 0.038 & 0.0368 \\
\hline & Freezing & 0.0129 & 0.0031 \\
\hline & Mean & 0.0135 & \\
\hline \multirow{3}{*}{$50 \%$} & Cooling & 0.0129 & 0.07038 \\
\hline & Freezing & 0.1956 & 0.00547 \\
\hline & Mean & 0.1879 & \\
\hline
\end{tabular}

According to Cavalcanti-Mata et al. (2012), the activation energy within chemical kinetics is the minimum energy required for a chemical reaction to occur. Fig. 2 and 3 show, respectively, the effective thermal diffusivity obtained from the Fourier model for the first term of the series, and the model I by Cavalcanti-Mata \& Duarte for the temperature of $-150^{\circ} \mathrm{C}(123 \mathrm{~K})$, with water content ranging from $10 \%$ to $50 \%$ wet basis. Due to this aspect, the modified Arrhenius equation was used (Equation 12). This equation results in the value of the activation energy of lima bean freezing kinetics of $5,355 \mathrm{~kJ} \mathrm{~mol}^{-1}$ for the Fourier model using the first term of the series, and of 4,42 $\mathrm{kJ} \mathrm{mol}^{-1}$ for the model I by Cavalcanti-Mata \& Duarte.

The activation energy values obtained are close to those found by Cavalcanti-Mata et al. (2012) for the frozen beans at $-25^{\circ} \mathrm{C},-50^{\circ} \mathrm{C},-170^{\circ} \mathrm{C}$, and $-196^{\circ} \mathrm{C}$, which was $3,95 \mathrm{~kJ} \mathrm{~mol}^{-1}$ when the authors used the Fourier model using the first term of series, and of $2,85 \mathrm{~kJ} \mathrm{~mol}^{-1}$ when they used the model I by Cavalcanti-Mata $\&$ Duarte. 


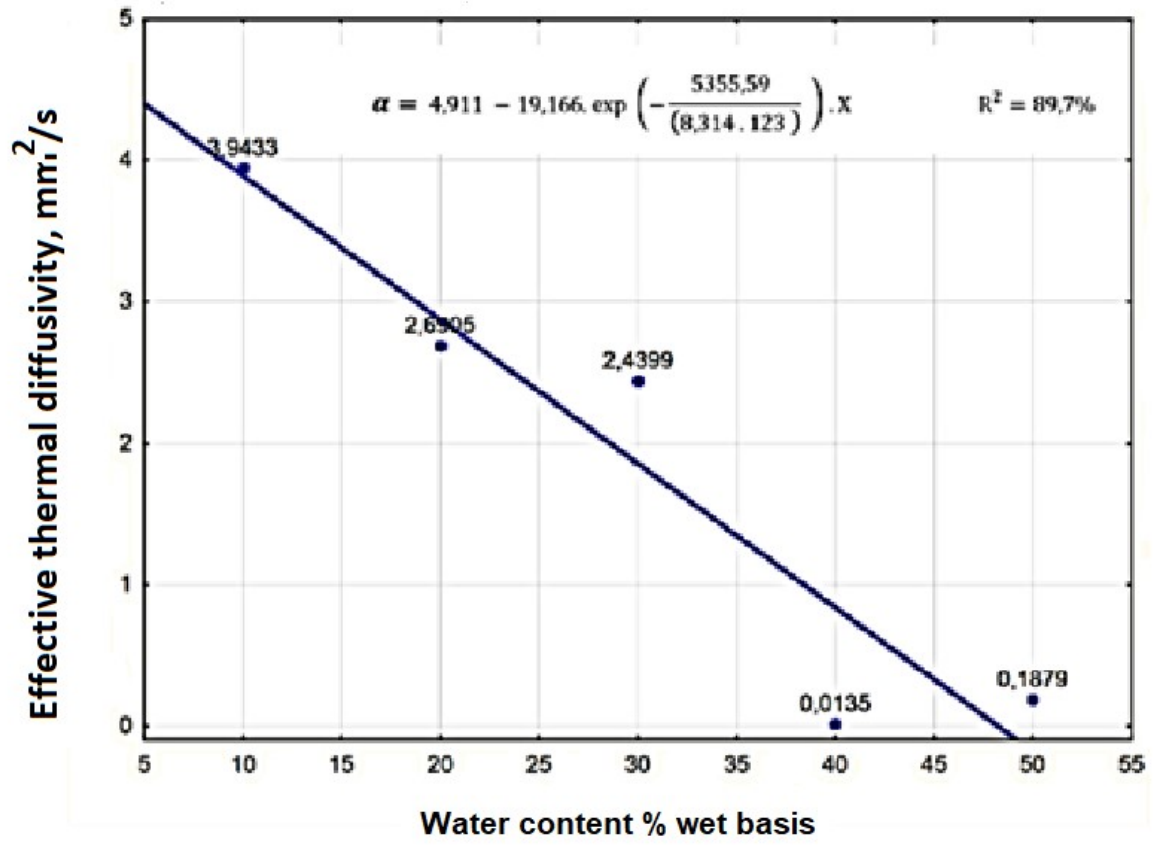

FIGURE 2. Effective thermal diffusivity obtained from the Fourier Model for the $1^{\text {st }}$ term.

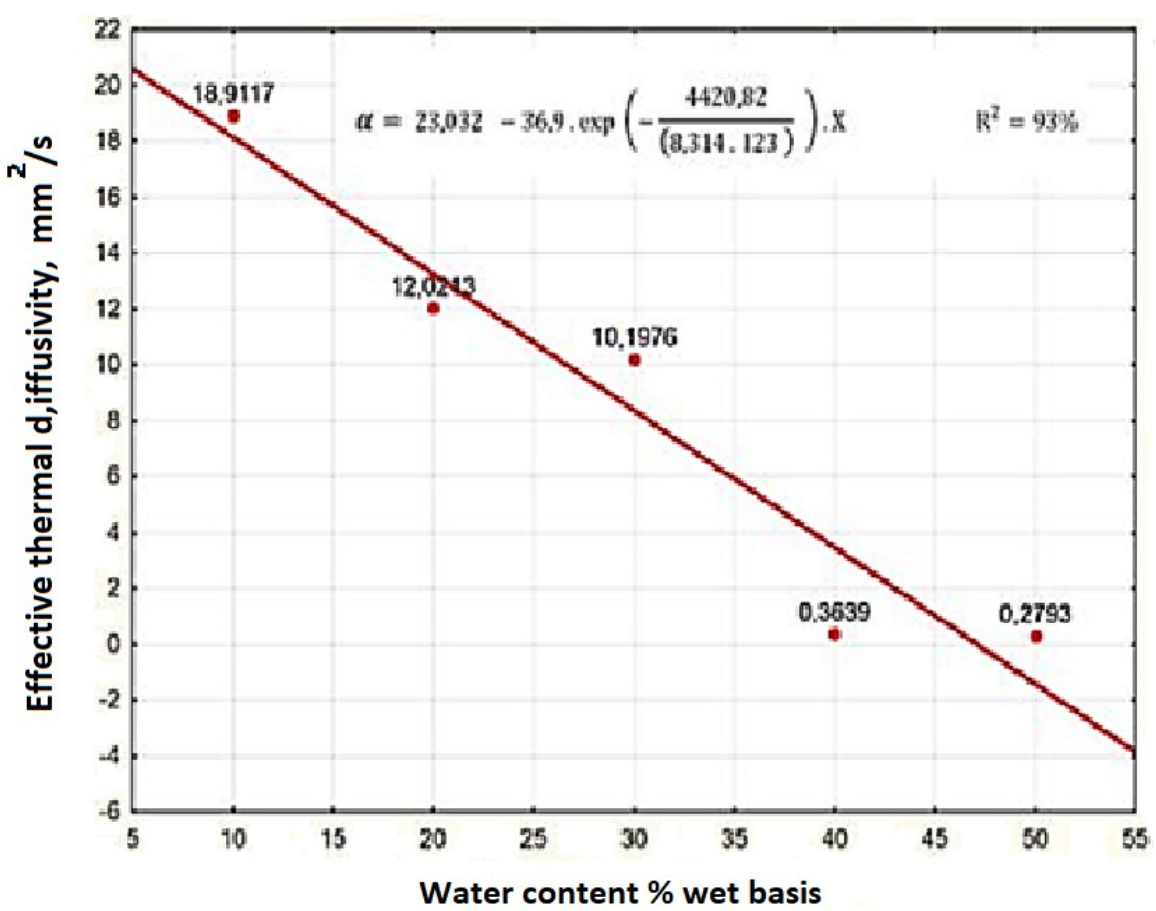

FIGURE 3. Effective thermal diffusivity obtained from Cavalcanti-Mata \& Duarte Model I

\section{Physiological quality of the lima bean seed}

Table 7 shows the percentages of germination and vigor of the lima bean seed determined before and after cryopreservation at $-150^{\circ} \mathrm{C}$. 
TABLE 7. Germination and vigor of lima bean seeds before cryopreservation and after 30 days of cryopreservation at $-150{ }^{\circ} \mathrm{C}$.

\begin{tabular}{ccccc}
\hline \multirow{2}{*}{$\begin{array}{c}\text { Water content } \\
\text { (\% wb) }\end{array}$} & \multicolumn{2}{c}{ GERMINATION (\%) } & \multicolumn{2}{c}{ VIGOR (\%) } \\
\cline { 2 - 5 } & $\begin{array}{c}\text { Before } \\
\text { cryopreservation }\end{array}$ & $\begin{array}{c}30 \text { days after } \\
\text { cryopreservation }\end{array}$ & Before cryopreservation & $\begin{array}{c}30 \text { days after } \\
\text { cryopreservation }\end{array}$ \\
\hline $\mathbf{1 0}$ & $98.5 \mathrm{Aa}$ & $98.5 \mathrm{Aa}$ & $87.5 \mathrm{Aa}$ & $87.5 \mathrm{Aa}$ \\
$\mathbf{2 0}$ & $98.5 \mathrm{Aa}$ & $99.0 \mathrm{Aa}$ & $87.5 \mathrm{Aa}$ & $86.0 \mathrm{Bb}$ \\
$\mathbf{3 0}$ & $98.5 \mathrm{Aa}$ & $98.0 \mathrm{Ab}$ & $87.5 \mathrm{Aa}$ & $85.0 \mathrm{Cc}$ \\
$\mathbf{4 0}$ & $98.5 \mathrm{Aa}$ & $97.0 \mathrm{Bc}$ & $87.5 \mathrm{Aa}$ & $83.0 \mathrm{Bd}$ \\
$\mathbf{5 0}$ & $98.5 \mathrm{Aa}$ & $96.5 \mathrm{Bc}$ & $87.5 \mathrm{Aa}$ & $73.5 \mathrm{Be}$ \\
\hline
\end{tabular}

* Means followed by the same upper-case letters in the row and lower-case letters in the column do not differ at the 5\% probability level by the Tukey test. SMD = Significant Minimum Difference.

Table 7 shows that the lima bean seeds with water contents of $10 \%$ and $20 \%$ wb show no significant changes in germination, however seed vigor is altered from a water content of $20 \% \mathrm{wb}$. This finding, even with storage of lima beans at cryogenic temperatures $\left(-150^{\circ} \mathrm{C}\right)$, confirms the statements made by Marcos Filho (2005) and accepted by Advíncula et al. (2016), that the higher the seed water content (lima beans), the lower the percentage of seed germination and vigor. Based on the data in table 7, it can be stated that the cryogenic temperature affected the lima bean seeds with water content above $10 \%$ wb in some way. Therefore, the conclusion is that the lima bean seeds should be cryopreserved with this water content so that physiological quality (germination and vigor) is not affected. However, in his work with cryopreservation Lefchak (2016) states that neither rapid freezing nor slow freezing was efficient for maintaining the physiological quality of $A$. angustifolia and A. uniflora seeds. This can be explained by the fact that not all seeds tolerate conservation by cold and, in a deeper analysis, are characterized as intermediate seeds (Goldfarb et al., 2017). Nevertheless, Faria et al. (2016) found that seeds of Physalis angulata can be stored in the long term without losing germinative potential through cryopreservation.

\section{CONCLUSIONS}

This study focused on the influence of the water content of lima bean, which ranged from 50 to $10 \% \mathrm{wb}$, on the kinetic behavior of its seeds at a cryogenic temperature of $-150{ }^{\circ} \mathrm{C}$. The conclusion was that the seeds of lima bean at a water content of $10 \% \mathrm{wb}$, after being cryostored at -150 ${ }^{\circ} \mathrm{C}$ for 30 days, was the one that maintained its physiological quality (germination and vigor) and, therefore, should be indicated for cryopreservation.

Another conclusion is that when the lima bean seed was treated as a sphere, its radius ranged from $4.983 \mathrm{~mm}$ to $6.184 \mathrm{~mm}$ depending on its water content in the range of $10 \%$ to $50 \% \mathrm{wb}$, and when these data were applied to the models that define the kinetic behavior of cryopreservation at $-150{ }^{\circ} \mathrm{C}$, they indicated that model II by Cavalcanti-Mata $\&$ Duarte was the one that best fit the experimental data, and that model I by Cavalcanti-Mata \& Duarte allows to determine the variation of thermal diffusivity as a function of water content $\left(0.2793\right.$ to $\left.18.91 \mathrm{~mm}^{2} . \mathrm{s}^{-1}\right)$, obtaining an activation energy of 4,42 $\mathrm{kJ} \mathrm{mol}^{-1}$.

\section{REFERENCES}

Advíncula TL, De Nadai FB, Nobre ADC, Ferreira ÉNMB, Brandão Júnior DS, Costa CA (2016) Qualidade física e fisiológica de sementes de Phaseolus lunatus L. Revista Brasileira de Ciências Agrárias (Agrária) 10(3):341-346.

Amaral DS, Sartor FR, Félix PHD, Cavalcanti-Mata MERM, Duarte MEM, Moura Neto LG (2010)

Determinação da difusividade e da energia de ativação para o grão de bico com base na cinética de congelamento. In: Congresso de Pesquisa e Inovação da Rede Norte Nordeste de Educação Tecnológica - CONNEPI. Maceió, IFAL, Anais...

Brasil (2009) Ministério da Agricultura, Pecuária e Abastecimento. Secretaria de Defesa Agropecuária. Regras para análise de sementes. Brasília: MAPA, 398p.

Cavalcanti-Mata MERM, Duarte MEM (2016) Teoria e modelos matemáticos para congelamento de sementes. Boletim de Pesquisa. Campina Grande: UFCG, 190p.

Cavalcanti-Mata MERM, Morais JO, Duarte MEM, Farias PA, Queiroz AJM (2012) Cinética de congelamento do feijão (Phaseolus vulgaris L.) a baixas temperaturas. Revista Brasileira de Engenharia Agrícola e Ambiental 16(6):667-674.

Cavalcanti-Mata MERM (2015) Crioconservação dos recursos fitogenéticos de espécies florestais, medicinais e de interesse econômico do semiárido do Nordeste do Brasil. UFCG, Boletim de Pesquisa, Campina Grande: UFCG, 180p.

Faria CVN, Paiva R, Freitas RT, Figueiredo JRM, Silva DPC, Reis MV (2016) Criopreservação de sementes de Physalis angulata L por meio da desidratação em sílica gel. Plant Cell Culture Micropropagation 12(2)27-33.

Feitosa RM, Silva RC, Melo JCS, Dyalla A, Lins F, Pê PR, Oliveira, SN (2017) Cinética de congelamento e difusividade térmica efetiva do feijão lima. Revista Agropecuária Técnica 38(3):147-152.

Frazão JEM, Santos D, Oliveira FP, Pereira WE, Morais JF (2010) Morfologia e fenologia de dez variedades de lima nas fases vegetativa e de inflorescência. Agropecuária Técnica 31(1):18-24. 
Goldfarb M, Cavalcanti Mata MERM, Duarte MEM (2017) Crioconservação de sementes oleaginosas Revista Brasileira de Produtos Agroindustriais 19(1):117-125.

Goneli ALD, Vieira MC, Benitez VHC, Gonçalves AA (2014) Modelagem matemática e difusividade efetiva de folhas de aroeira durante a secagem. Pesquisa Agropecuária Tropical 44(1):56-64.

Guimarães WNR, Martins LSS, Silva EF, Ferraz GMG, Oliveira FJ (2007) Caracterização morfológica e molecular de acessos de feijão-lima (Phaseolus lunatus L.). Revista Brasileira de Engenharia Agrícola Ambiental 11(1):37-45.

Horn MM, Martins VCA, Plepis AMG (2010)

Determinação da energia de ativação em hidrogéis poliméricos a partir de dados termogravimétricos. Polímeros 20(3):201-204.

Incropera FP, De Witt DP (1996) Fundamentals of heat and mass transfer. New York: John Wiley \& Sons, 997p.

Lefchak AS (2016) Influência de crioprotetores e da criopreservação sobre a qualidade fisiológica de sementes de Araucaria angustifolia e Eugenia uniflora. Trabalho de Conclusão de Curso (Agronomia). Universidade Federal da Fronteira Sul, Laranjeiras do Sul.

Marcos Filho JM (2005) Fisiologia de sementes de plantas cultivadas. Piracicaba: FEALQ, 495p.
Mohapatra D, Rao PS (2005) A thin layer drying model of parboiled wheat Journal of Food Engineering 66(4):513-518.

Mohsenin NN (1980) Physical properties of plant and animal materials: structure, physical characteristics and mechanical properties. New York: Gordon and Breach Science Publishers, 742 p.

Oliveira FN, Torres SB, Bebedito CP (2011)

Caracterização botânica e agronômica de acessos de feijãolima. Revista Caatinga 1(1):143-148.

Origin 2017 (2016) Tutorial for Origin. Available: https://www.originlab.com/pdfs/Origin2017

_Documentation/English/Origin_Tutorial_2017_E.pdf. Accessed: Nov 27, 2017.

Santos e Silva FA, Azevedo CAV (2016) The Assistat software version 7.7 and its use in the analysis of experimental data. African Journal of Agricultural Research 11(39):3733-3740.

Silva LMM, Cavalcanti Mata MERM, Duarte MEM (2015) Teor de água limite para crioconservação de sementes de romã (Punica granatum L.). Engenharia Agrícola 35(2):313-321. 